\title{
Assessment of Insecticidal Properties of Products From Seeds of Carica papaya Against Callosobruchus Maculatus (Fabricius)
}

\author{
Joy Ejemen Idoko (Corresponding Author) \\ Federal University of Technology, P.M.B. 704, Akure, Nigeria \\ Tel: 234-803-472-5952 E-mail address: jeidoko@yahoo.com, jeidoko@futa.edu.ng
}

Bukola Mary Atere

Federal University of Technology, P.M.B. 704, Akure, Nigeria

Tel: 234-706-781-2847 E-mail address: aterebukolam@gmail.com, bookhollarmary@yahoo.com

Raphael Abiodun Adebayo

Federal University of Technology, P.M.B. 704, Akure, Nigeria

Tel: 234-703-866-1128 E-mail address: raadebayo@ futa.edu.ng

Received: June 19, 2018 Accepted: August 28, 2018

doi:10.5296/jas.v6i3.13645 URL: https://doi.org/10.5296/jas.v6i3.13645

\begin{abstract}
Powder and ash of Carica papaya seed extracted from riped and unriped C. papaya fruits obtained from Teaching and Research Farm of the Federal University of Technology, Akure were evaluated for their insecticidal potential against Callosobruchus maculatus (Fabricius) at application rates of $0.0,0.2,0.4,0.6,0.8$ and $1.0 \mathrm{~g}$ per $20 \mathrm{~g}$ of cowpea seeds. The experiment was carried out at the pest management laboratory of the Department of Crop, Soil and Pest Management under ambient laboratory conditions of $27 \pm 2{ }^{0} \mathrm{C}$ temperature and $70 \pm 5 \%$ relative humidity. Each treatment was infested with 5 pairs of $C$. maculatus. The experiment was laid out in Completely Randomized Design with each treatment replicated three times. Mortality of cowpea beetles were assessed at 24, 48 and 72hours post treatment. Thereafter data were collected on oviposition, adult emergence, weevil perforation index and
\end{abstract}


seed germination. The results obtained indicated that adult mortality of $C$. maculatus increased with increasing application rates of powders and ashes of ripe and unripe $C$. papaya seeds. $100 \%$ mortality was observed on cowpea seeds treated with powders and ashes of unripe $C$. papaya seed at 0.8 and $1.0 \mathrm{~g}$ application rates at 72 hours post treatment. Powders and ashes of unripe $C$. papaya seed significantly reduced the oviposition potential of adult $C$. maculatus and caused significant reduction of damaged seeds. Highest number of seeds that germinated was recorded on the seeds treated with powders and ashes of unripe $C$. papaya seed at 0.8 and $1.0 \mathrm{~g}$ application rates.

Keywords: Carica papaya, Callosobruchus maculatus, weevil perforation index

\section{Introduction}

Callosobruchus maculatus is a principal cosmopolitan pest of cowpea which causes substantial qualitative and quantitative loss manifested by seed perforation, reduction in seed weight, market value and seed viability (Ofuya et al., 2010). It has the ability to infest and re-infest many species of cowpea resulting in enormous post-harvest loss, the success of which is attributed to short generation time and high fecundity (Tarver et al., 2006). Control of this insect pest relies heavily on the use of synthetic insecticides but the increasing cost of application and their hazardous effects in the environment have become a source of concern. For these reasons, alternative chemicals for pest control are being sourced from plants (Berger, 1994). This is exacerbated by the fact that the pesticides toxicity also has adverse effects on non-target organisms (Chitamba et al., 2013) as well as the environment that leads to acute or chronic poisoning.

The use of plant derived insecticides played an important role in the traditional method of storage pest control in Africa and Asia (Bekele and Hassanali, 2001). Recently, a number of plant materials have been explored as sustainable alternatives for controlling short-lived insect pests during storage of grains and found to be quite effective. Some of the advantages of these botanical pesticides are their availability and user-friendliness as biological control agents with no adverse effects on the environment and the user.

Nigeria is one of the largest producer of papaya (Carica papaya) in Africa (Edward et al., 2015). The annual production of $C$. papaya is around 1500 tons, and of this total, $99 \%$ is destined for domestic consumption (Porte et al., 2011). This has led to a quantum number of environmental pollution generated from the fruit within the country. Taking into consideration the large number of seeds from a single fruit, one of the solutions to alleviate this problem would be the use of these seeds as a source of botanical insecticides (Azevedo and Campagnol, 2014). Therefore, it will be interesting to investigate the possibility of controlling cosmopolitan pests of cowpea in storage using these pollutants. In Nigeria, the efficacies of most of these botanical preparations have been investigated by some researchers (Idoko, 2015). However, little have been done on the possibility of using pollutants obtained from the disposal of pawpaw seeds for the control of storage pest. This study seeks to assess the insecticidal properties of ripe and unripe Carica papaya (L.) seed (powder and ash) on $C$. maculatus (F.). 


\section{Materials and Methods}

The study was carried out at the Pest Management laboratory of the Department of Crop, Soil and Pest Management, Federal University of Technology, Akure, Ondo State, Nigeria (Latitude $7^{0} 16^{\prime} \mathrm{N}$ and Longitude $15^{\circ} 12^{\prime} \mathrm{E}$ ) under ambient laboratory conditions of $27 \pm 2^{0} \mathrm{C}$ temperature and $70 \pm 5 \%$ relative humidity.

\subsection{Collection and Preparation of Cowpea seeds}

Clean uninfested cowpea seeds (Oloyin variety) used for the experiment were obtained from a grain store at, Akure, Ondo State, Nigeria. The seeds were properly sieved and handpicked thus ensuring that only healthy seeds were used while the unhealthy and damaged seeds were discarded. The seeds were cold sterilized in the refrigerator at $10^{0} \mathrm{C}$ for about 2 weeks to disinfect the seeds. The seeds were thereafter acclimatized to laboratory conditions for $24 \mathrm{hr}$ before use.

\subsection{Insect culture experimental condition}

The $C$. maculatus that were used for the study were derived from colony originating from already infested cowpea and maize seeds obtained from Pest Management Laboratory, FUTA, Ondo State, Nigeria. Ten pairs of adult $C$. maculatus were introduced into 2 litres plastic containers and allowed to oviposit for 7 days before they were sieved out. The infested seeds were kept in the laboratory and observed daily for emergence of adults. This culture was maintained and used thereafter as source of $C$. maculatus and $S$. zeamais for the experiment.

\subsection{Preparation of Unripe and Ripe Carica papaya seed powder}

The pawpaw seeds (ripe and unripe) used for this study were extracted from pawpaw fruits obtained from FUTA Teaching and Research farm, Akure, Ondo State, Nigeria. The seeds were air dried for 21 days to ensure that volatile active compounds are retained in the dried samples. Each sample was pulverized in the laboratory using kitchen electric grinding machine and then sieved through a $0.5 \mathrm{~mm}$ mesh. The pulverized samples were kept in separate air tight containers and placed in a wooden cupboard in the laboratory for use in subsequent bioassays.

\subsection{Preparation of Unripe and Ripe Carica papaya seed ash extract}

Pulverized C. papaya seeds (ripe and unripe) were kept separately in different clay pots and were heated in a muffle furnace and maintained at $550^{\circ} \mathrm{C}$ for $4 \mathrm{hr}$ to obtain the ashes which were later kept in an airtight container.

2.5 Effects and damage assessment of powders of ripe and unripe pawpaw (C. papaya) seeds on C. maculatus

The powder of both ripe and unripe $C$. papaya seed were tested at 0 (control), 0.2, 0.4, 0.6, 0.8 and $1 \mathrm{~g}$ per $20 \mathrm{~g}$ of clean (uninfested)cowpea seed in separate plastic containers. Each plastic container was tumbled several times to ensure homogenous mixing of powder with grains. Five pairs of $C$. maculatus were introduced into each container. Adult mortality was monitored and counted at 24, 48 and 72 hours after infestation (HAI). Adult weevils were 
removed and each container was monitored until the emergence of F1 progeny. Emerged adults were removed, counted and recorded. The grains in each plastic container were reweighed by using Mettler weighing balance and the data obtained were used to compute \% weight loss using the formula:

$$
\% \text { Weight loss }=\frac{\text { Initial Weight }- \text { Final Weight }}{\text { Initial Weight }} \times \frac{100}{1}
$$

The numbers of damaged and undamaged seeds were counted, weighed and recorded. This was carried out by removing the grains in each treatment and separating them into damaged (grains with holes) and undamaged (grains without holes). The seed damage data were used to estimate the weevil perforation index (WPI)

$$
\mathrm{WPI}=\frac{\% \text { treated seeds perforated }}{\% \text { treated seeds perforated }+\% \text { control seeds perforated }} \times \frac{100}{1}
$$

\subsection{Effects and damage assessment of ash of ripe and unripe pawpaw (C. papaya) seeds on} C. maculatusin stored maize grains

The ash of ripe and unripe $C$. papaya was tested at $0.2 \mathrm{~g}, 0.4 \mathrm{~g}, 0.6 \mathrm{~g}, 0.8 \mathrm{~g}$ and $1.0 \mathrm{~g} / 20 \mathrm{~g}$ of clean (uninfested) maize grains in separate plastic containers. Each container was tumbled several times to ensure homogenous mixing of powder with grains. Five pairs of $C$. maculatuswere introduced into each plastic container. A control treatment with no addition of C. papaya seed ash onto the seeds was also set up. Adult mortality was monitored and counted at 24, 48 and 72 hour after infestation (HAI) and thereafter all insects were removed. Also, Adults that emerged from hatched eggs were also counted as from 21 days after infestation. The numbers of damaged and undamaged seeds were counted, weighed and recorded. The seed damage data were used to estimate the weevil perforation index (WPI).

\subsection{Effect of ashes and powders of pawpaw (C. papaya) seeds on seed germination}

Seed germination test was carried out on 10 seed samples (undamaged) randomly selected from each treatment immediately after final weight was taken. The seeds were placed in Petri dishes containing moistened filter paper (Whatman No. 1) and arranged in the laboratory. From 3-6 days the number of germinated seedlings from each Petri dish was counted and recorded.

$$
\text { Germinaition } \%=\frac{\text { No. of seeds germinated }}{\text { Total seeds sampled }} \times \frac{100}{1}
$$

\subsection{Experimental Design and Data Analysis}

The Experimental Design which was adopted for the experiment is Completely Randomized Design (CRD) and each treatment was replicated three times. All data obtained were subjected to analysis of variance (ANOVA) using SPSS version 16. Where necessary, data were transformed before analysis (percentage data were arc-sine transformed while data based on counting were square root transformed). Means were separated using Tukey's test at $5 \%$ level of significance. All data collected were subjected to simple linear correlation and 
regression analysis. Data collected on seeds that were holed after F1 progeny emergence were used to compute weevil perforation index, Fatope et al. (1995).

\section{Results}

Table 1. Effect of powder and ash of riped and unriped $C$. papaya seed on percentage mortality of $C$. maculatus at 24,48 and 72 hours post treatment.

\begin{tabular}{|c|c|c|c|c|}
\hline $\begin{array}{l}\text { Concentration } \\
\text { of Powder/Ash } \\
\text { (g) }\end{array}$ & $\begin{array}{l}\text { Riped } C \text {. } \\
\text { papaya } \\
\text { Powder }\end{array}$ & $\begin{array}{c}\text { Unriped } C \text {. } \\
\text { papaya } \\
\text { Powder }\end{array}$ & $\begin{array}{c}\text { Riped } C . \\
\text { Papaya } \\
\text { Ash }\end{array}$ & $\begin{array}{l}\text { Unriped } C \text {. } \\
\text { Papaya Ash }\end{array}$ \\
\hline \multicolumn{5}{|c|}{24 hours } \\
\hline 0.0 & $0.0 \pm 0.00 \mathrm{a}$ & $0.0 \pm 0.00 \mathrm{a}$ & $0.0 \pm 0.00 \mathrm{a}$ & $6.7 \pm 3.33 \mathrm{a}$ \\
\hline 0.2 & $3.3 \pm 3.33 \mathrm{ab}$ & $3.3 \pm 3.33 \mathrm{ab}$ & $6.7 \pm 3.33 \mathrm{ab}$ & $16.7 \pm 6.67 \mathrm{ab}$ \\
\hline 0.4 & $16.7 \pm 6.67 b c$ & $16.7 \pm 6.67 \mathrm{bc}$ & $23.3 \pm 8.82 b c$ & $20.0 \pm 8.82 \mathrm{abc}$ \\
\hline 0.6 & $16.7 \pm 6.67 \mathrm{bc}$ & $16.7 \pm 6.67 b c$ & $23.3 \pm 3.33 b c$ & $33.3 \pm 3.33 b c$ \\
\hline 0.8 & $20.0 \pm 5.77 b c$ & $20.0 \pm 5.77 b c$ & $30.0 \pm 0.00 \mathrm{c}$ & $33.3 \pm 0.00 \mathrm{bc}$ \\
\hline 1.0 & $26.7 \pm 3.33 c$ & $26.7 \pm 3.33 c$ & $36.7 \pm 3.33 c$ & $46.7 \pm 3.33 c$ \\
\hline \multicolumn{5}{|c|}{48 hours } \\
\hline 0.0 & $3.3 \pm 3.33 \mathrm{a}$ & $6.7 \pm 3.33 \mathrm{a}$ & $6.7 \pm 3.33 \mathrm{a}$ & $16.7 \pm 3.33 \mathrm{a}$ \\
\hline 0.2 & $10.0 \pm 5.77 \mathrm{ab}$ & $20.0 \pm 0.00 \mathrm{ab}$ & $13.3 \pm 3.33 \mathrm{ab}$ & $33.3 \pm 3.33 \mathrm{ab}$ \\
\hline 0.4 & $20.0 \pm 5.77 \mathrm{ab}$ & $30.0 \pm 5.77 \mathrm{bc}$ & $23.3 \pm 3.33 \mathrm{abc}$ & $36.7 \pm 8.82 \mathrm{abc}$ \\
\hline 0.6 & $23.3 \pm 3.33 \mathrm{ab}$ & $46.7 \pm 8.82 b c$ & $43.3 \pm 8.82 b c$ & $53.3 \pm 3.33 \mathrm{bcd}$ \\
\hline 0.8 & $33.3 \pm 8.82 b$ & $50.0 \pm 5.77 b c$ & $46.7 \pm 3.33 c$ & $60.0 \pm 0.00 \mathrm{~cd}$ \\
\hline 1.0 & $40.0 \pm 5.77 \mathrm{~b}$ & $53.3 \pm 6.67 \mathrm{c}$ & $50.0 \pm 10.00 \mathrm{c}$ & $63.3 \pm 6.67 d$ \\
\hline \multicolumn{5}{|c|}{72 hours } \\
\hline 0.0 & $6.7 \pm 6.67 \mathrm{a}$ & $16.7 \pm 8.82 \mathrm{a}$ & $13.3 \pm 6.67 \mathrm{a}$ & $30.0 \pm 5.77 \mathrm{a}$ \\
\hline 0.2 & $23.3 \pm 3.33 \mathrm{ab}$ & $30.0 \pm 0.00 \mathrm{a}$ & $23.3 \pm 3.33 \mathrm{ab}$ & $43.3 \pm 3.33 \mathrm{ab}$ \\
\hline 0.4 & $30.0 \pm 5.77 b$ & $40.0 \pm 5.77 \mathrm{a}$ & $33.3 \pm 3.33 \mathrm{ab}$ & $46.7 \pm 8.82 \mathrm{ab}$ \\
\hline 0.6 & $33.3 \pm 3.33 b$ & $63.3 \pm 3.33 b$ & $53.3 \pm 8.82 b$ & $86.7 \pm 3.33 b$ \\
\hline 0.8 & $76.7 \pm 3.33 c$ & $100.0 \pm 0.00 \mathrm{~b}$ & $96.7 \pm 3.33 c$ & $100.0 \pm 0.00 c$ \\
\hline 1.0 & $83.3 \pm 3.33 c$ & $100.0 \pm 0.00 \mathrm{~b}$ & $100.0 \pm 0.00 \mathrm{c}$ & $100.0 \pm 0.00 \mathrm{c}$ \\
\hline
\end{tabular}


Each value is the mean \pm standard error of the three replicates. Values in the same column with the same letter(s) do not differ significantly at $\mathrm{p} \leq 0.05$ using Tukey's honest significance test

Table 1 shows the percentage mortality counts of adult $C$. maculatus exposed to the different concentrations of powder and ash of riped and unriped $C$. papaya seed at $24 \mathrm{~h}, 48 \mathrm{~h}$ and $72 \mathrm{~h}$ after infestation. Generally, adult mortality of $C$. maculatus was higher in all treatments at $1.0 \mathrm{~g}$ application rate. The different concentrations of the powder and ash of $C$. papaya seed exhibited varying degrees of insecticidal activities killing adult $C$. maculatus in the treated seeds more than the untreated seeds $(\mathrm{p}<0.05)$. Adult mortality increased with length of exposure. There were significant differences in the mortalities of $C$. maculatus at the different treatment conditions compared to the untreated control. At 24 hours after infestation, the highest number of adult mortality was recorded at the treatment comprising of unriped $C$. papaya seed ash at $1.0 \mathrm{~g}$ application rate $(46.7 \%)$ while the control experiment recorded the least adult mortality. At 48 hours post treatment, a similar trend was observed. Unriped $C$. papaya seed ash recorded the highest adult mortality (63.3\%). All treatments recorded higher adult mortality of $C$. maculatus $(\mathrm{p}<0.05)$ in cowpea seeds than in the control experiment. All the treatments showed weevil mortality ranging from $6.7 \%$ to $100.0 \%$ at 72 hours post treatment. $100 \%$ kill of $C$. maculatus were observed in treatments comprising of unriped $C$. papaya seed powder, riped $C$. papaya seed ash and unriped $C$. papaya seed ash respectively at application rates of $0.8 \mathrm{~g}$ and above. Adult mortality increased with length of exposure.

The lethal dosage of $C$. papaya seed powder and ash required to achieve 50 and $95 \%$ insect mortality after $24 \mathrm{~h}, 48 \mathrm{~h}$ and $72 \mathrm{~h}$ of exposure is presented in Table 2 . The ash of unripe $C$. papaya seed appeared the most effective as it required the lowest amount of concentration to achieve 50 and $95 \%$ (0.94 and 2.19\%, respectively) insect mortality after 24 hours of exposure. Ripe and unripe $C$. papaya seed ash however appeared to be more effective than the powder of ripe and unripe C. papaya seed.

The results of lethal doses $\left(\mathrm{LD}_{50}\right.$ and $\left.\mathrm{LD}_{95}\right)$ of powder and ash of $C$. papaya on $C$. maculatus at 48 hours of exposure is presented in Table 2. The results obtained showed that powder of ripe $C$. papaya seed recorded $\mathrm{LD}_{50}$ of 1.13 and $\mathrm{LD}_{95} \mathrm{of} 2.22$ while powder of unripe $C$. papaya seed recorded $\mathrm{LD}_{50}$ of 0.83 and $\mathrm{LD}_{95}$ of 2.12 , ripe $C$. papaya seed ash recorded $\mathrm{LD}_{50}$ of 0.89 and $\mathrm{LD}_{95}$ of 1.96 while ash of unripe $C$. papaya seed recorded $\mathrm{LD}_{50}$ of 0.60 and $\mathrm{LD}_{95}$ of 1.83.From the results obtained, it was deduced that unripe $C$. papaya seed ash appeared to be the most effective in all the treatments. While powder of ripe $C$. papaya seed is the less effective of all the treatments.

The results of lethal doses $\left(\mathrm{LD}_{50}\right.$ and $\left.\mathrm{LD}_{95}\right)$ of powder and ash of $C$. papaya on $C$. maculatus at 72 hours of exposure is presented in Table 2. The results obtained indicated that the application of the ripe and unripe $C$. papaya seed ash at lower rates would cause $50 \%$ and 95\% mortality of bruchids, while application of ripe and unripe $C$. papaya seed powder at higher rates will be required to kill $50 \%$ and $95 \%$ of the insects at 72 hours of exposure. The powder of ripe $C$. papaya seed $(0.46-0.83$ and $1.01-2.17)$ appeared to be less effective when compared to the ash of ripe $C$. papaya seed $(0.35-0.59$ and $0.75-1.27)$ as indicated by 
the application rate which caused $50 \%$ and $95 \%$ mortality respectively in cowpea beetles. In addition, fiducial limits revealed that $0.24-0.52$ and $0.73-1.35$ powder of unripe $C$. papaya seed is required to kill $50 \%$ and $95 \%$ of the weevils respectively when compared to unripe $C$. papaya seed ashwith 0.09-0.38 and $0.59-1.19$. This further revealed that ash of ripe and unripe $C$. papaya seed was more effective in controlling $C$. maculatus at a lower concentration compared with powder of ripe and unripe $C$. papaya seed.

Table 2. Lethal dose $\left(\mathrm{LD}_{50}\right.$ and $\left.\mathrm{LD}_{95}\right)$ of powder and ash of $C$. papaya seed on Callosobruchus maculatus at 24, 48 and 72 hours of exposure

\begin{tabular}{|c|c|c|c|c|c|c|c|}
\hline $\begin{array}{c}\text { Plant } \\
\text { material }\end{array}$ & $\begin{array}{c}\text { Plant } \\
\text { materials }\end{array}$ & $\begin{array}{c}\text { Slope } \pm \\
\text { S. E }\end{array}$ & $\begin{array}{c}\text { Intercept } \\
\pm \mathrm{S} \text {. E }\end{array}$ & $X^{2}$ & $\begin{array}{c}\mathrm{LD}_{50} 50 \% \\
\mathrm{FL}\end{array}$ & $\mathrm{LD}_{95} 95 \% \mathrm{FL}$ & P-value \\
\hline \multirow{4}{*}{ Powder } & \multicolumn{7}{|c|}{24 hours } \\
\hline & Ripe & $\begin{array}{c}1.53 \pm \\
0.71\end{array}$ & $\begin{array}{c}-1.94 \pm \\
0.50\end{array}$ & 2.53 & $\begin{array}{ll}1.27 & 0.91 \\
-7.17 & \end{array}$ & $\begin{array}{l}2.351 .52 \\
-18.33\end{array}$ & 0 \\
\hline & Unripe & $\begin{array}{c}1.53 \pm \\
0.71\end{array}$ & $\begin{array}{c}-1.94 \pm \\
0.50\end{array}$ & 2.53 & $\begin{array}{ll}1.27 & 0.91 \\
-7.17 & \end{array}$ & $\begin{array}{l}2.35 \quad 1.52 \\
-18.33\end{array}$ & 0 \\
\hline & Ripe & $\begin{array}{c}1.51 \pm \\
0.63\end{array}$ & $\begin{array}{c}-1.71 \pm \\
0.44\end{array}$ & 0.91 & $\begin{array}{ll}1.13 & 0.83 \\
-3.46 & \end{array}$ & $\begin{array}{ll}2.22 & 1.48 \\
-9.28 & \end{array}$ & 0 \\
\hline Ash & Unripe & $\begin{array}{c}1.32 \pm \\
0.54\end{array}$ & $\begin{array}{c}-1.24 \pm \\
0.35\end{array}$ & 0.47 & $\begin{array}{ll}0.94 & 0.66 \\
-2.56 & \end{array}$ & $\begin{array}{ll}2.19 & 1.44 \\
-8.75 & \end{array}$ & 0 \\
\hline \multicolumn{8}{|c|}{48 hours } \\
\hline \multirow{3}{*}{ Powder } & Ripe & $\begin{array}{c}1.51 \pm \\
0.63\end{array}$ & $\begin{array}{c}-1.71 \pm \\
0.44\end{array}$ & 0.91 & $\begin{array}{ll}1.13 & 0.83 \\
-3.46 & \end{array}$ & $\begin{array}{ll}2.22 & 1.48 \\
-9.28 & \end{array}$ & 0 \\
\hline & Unripe & $\begin{array}{c}1.28 \pm \\
0.53\end{array}$ & $\begin{array}{c}-1.07 \pm \\
0.34\end{array}$ & 1.05 & $\begin{array}{ll}0.83 & 0.57 \\
-2.10 & \end{array}$ & $\begin{array}{ll}2.12 & 1.39 \\
-8.42 & \end{array}$ & 0 \\
\hline & Ripe & $\begin{array}{c}1.53 \pm \\
0.56\end{array}$ & $\begin{array}{c}-1.37 \pm \\
0.37\end{array}$ & 0.77 & $\begin{array}{ll}0.89 & 0.65 \\
-1.76 & \end{array}$ & $\begin{array}{ll}1.96 & 1.36 \\
-5.36 & \end{array}$ & 0 \\
\hline Ash & Unripe & $\begin{array}{c}1.34 \pm \\
0.51\end{array}$ & $\begin{array}{c}-0.81 \pm \\
0.31\end{array}$ & 0.01 & $\begin{array}{ll}0.60 & 0.32 \\
-1.11 & \end{array}$ & $\begin{array}{ll}1.83 & 1.24 \\
-5.66 & \end{array}$ & 0 \\
\hline \multicolumn{8}{|c|}{72 hours } \\
\hline \multirow{3}{*}{ Powder } & Ripe & $\begin{array}{c}2.27 \pm \\
0.58\end{array}$ & $\begin{array}{c}-1.40 \pm \\
0.36\end{array}$ & 2.34 & $\begin{array}{ll}0.62 & 0.46 \\
-0.83 & \end{array}$ & $\begin{array}{ll}1.34 & 1.01 \\
-2.17 & \end{array}$ & 0 \\
\hline & Unripe & $\begin{array}{c}3.65 \pm \\
0.77\end{array}$ & $\begin{array}{c}-1.71 \pm \\
0.41\end{array}$ & 4.41 & $\begin{array}{ll}0.47 & 0.35 \\
-0.59 & \end{array}$ & $\begin{array}{ll}0.92 & 0.75 \\
-1.27 & \end{array}$ & 0 \\
\hline & Ripe & $\begin{array}{c}3.09 \pm \\
0.70\end{array}$ & $\begin{array}{c}-1.19 \pm \\
0.35\end{array}$ & 3.79 & $\begin{array}{ll}0.38 & 0.24 \\
-0.52 & \end{array}$ & $\begin{array}{ll}0.92 & 0.73 \\
-1.35 & \end{array}$ & 0 \\
\hline Ash & Unripe & $\begin{array}{c}3.25 \pm \\
0.80\end{array}$ & $\begin{array}{c}-0.83 \pm \\
0.33\end{array}$ & 2.68 & $\begin{array}{ll}0.26 & 0.09 \\
-0.38 & \end{array}$ & $\begin{array}{ll}0.76 & 0.59 \\
-1.19 & \end{array}$ & 0 \\
\hline
\end{tabular}

$\mathrm{X}^{2}$ : Chi square, SE: Standard error, LD: Lethal dosage. FL represents fiducial limits 
Table 3. Mean Oviposition of C. maculatus in cowpea treated with different application rates of powder and ash of C. papaya.

\begin{tabular}{llccc}
\hline $\begin{array}{c}\text { Concentration } \\
\text { of Powder/Ash } \\
(\mathbf{g})\end{array}$ & $\begin{array}{c}\text { Ripe C.papaya } \\
\text { Powder }\end{array}$ & $\begin{array}{c}\text { Unripe } \boldsymbol{C} . \\
\text { papaya } \\
\text { Powder }\end{array}$ & $\begin{array}{c}\text { Ripe } \boldsymbol{C} \text {. papaya } \\
\text { Ash }\end{array}$ & $\begin{array}{c}\text { Unripe } \boldsymbol{C} . \\
\text { papaya } \\
\text { Ash }\end{array}$ \\
\hline $\mathbf{0 . 0}$ & $131.7 \pm 11.14 \mathrm{a}$ & $116.0 \pm 12.53 \mathrm{a}$ & $144.3 \pm 5.24 \mathrm{a}$ & $144.3 \pm 5.24 \mathrm{a}$ \\
$\mathbf{0 . 2}$ & $92.7 \pm 1.76 \mathrm{~b}$ & $82.0 \pm 2.65 \mathrm{~b}$ & $84.0 \pm 1.15 \mathrm{~b}$ & $76.7 \pm 2.40 \mathrm{~b}$ \\
$\mathbf{0 . 4}$ & $86.7 \pm 1.73 \mathrm{bc}$ & $66.7 \pm 5.17 \mathrm{c}$ & $83.3 \pm 2.91 \mathrm{~b}$ & $54.7 \pm 1.76 \mathrm{c}$ \\
$\mathbf{0 . 6}$ & $75.3 \pm 3.53 \mathrm{c}$ & $55.0 \pm 5.61 \mathrm{c}$ & $62.3 \pm 2.65 \mathrm{c}$ & $41.3 \pm 0.88 \mathrm{~d}$ \\
$\mathbf{0 . 8}$ & $67.7 \pm 5.86 \mathrm{c}$ & $30.0 \pm 1.15 \mathrm{~d}$ & $37.0 \pm 0.58 \mathrm{~d}$ & $29.7 \pm 1.20 \mathrm{e}$ \\
$\mathbf{1 . 0}$ & $52.0 \pm 13.00 \mathrm{~d}$ & $27.7 \pm 6.98 \mathrm{~d}$ & $29.0 \pm 2.65 \mathrm{~d}$ & $24.7 \pm 1.86 \mathrm{e}$ \\
\hline
\end{tabular}

Each value is the mean \pm standard error of the three replicates. Values in the same column with the same letter(s) do not differ significantly at $\mathrm{p} \leq 0.05$ using Tukey's honest significance test

The mean number of eggs laid by female $C$. maculatus on cowpea seeds treated with powder and ash of ripe and unripe $C$. papaya seed against $C$. maculatus is shown in Table 3 . The results showed that irrespective of the treatments, eggs laid by female weevils on treated cowpea seeds were fewer compared to the control experiment. However, treatment with $0.2 \mathrm{~g}$ of powder or ash of both ripe and unripe $C$. papaya recorded the highest number of eggs laid. Seeds treated with unripe $C$. papaya seed ash recorded the lowest number of eggs laid (24.7) at $1.0 \mathrm{~g}$ application rate. It was also observed that mean number of eggs laid decreases with increase in application rates of powder and ash of ripe and unripe C. papaya seed.

Each value is the mean \pm standard error of the three replicates. Values in the same column with the same letter(s) do not differ significantly at $\mathrm{p} \leq 0.05$ using Tukey's honest significance test

The percentages of adults $C$. maculatus that emerged from seeds of cowpea treated with powders and ashes of $C$. papaya seed are presented in Table 4 . The results showed that seeds treated with powder and ash of $C$. papaya seed significantly reduced $(\mathrm{p}<0.05)$ emergence of adults compared to the control. At application rates of $0.8 \mathrm{~g}$ and $1.0 \mathrm{~g}$ of ripe C. papaya seed powder, there were no significant $(\mathrm{p}>0.05)$ difference between the number of adults that emerged. A similar trend was obtained when unripe $C$. papaya seed powder and ripe $C$. papaya seed ash were tested at the same application rates against cowpea seed beetles. However, the lowest number of adults that emerged was recorded at $1.0 \mathrm{~g}$ application rates of powder and ash of unripe $C$. papaya seed. The results further showed that adult emergence reduced with increase in application rates of powder and ash of ripe and unripe $C$. papaya seed. 
Table 4. Mean Adult Emergence of $C$. maculatus in cowpea treated with different application rates of powder and ash of C. papaya.

\begin{tabular}{|c|c|c|c|c|}
\hline $\begin{array}{l}\text { Concentration } \\
\text { of Powder/Ash } \\
\text { (g) }\end{array}$ & $\begin{array}{c}\text { Ripe } C \text {. papaya } \\
\text { Powder }\end{array}$ & $\begin{array}{c}\text { Unripe } C \text {. } \\
\text { papaya } \\
\text { Powder }\end{array}$ & $\begin{array}{c}\text { Ripe C. papaya } \\
\text { Ash }\end{array}$ & $\begin{array}{c}\text { Unripe } C . \\
\text { papaya } \\
\text { Ash }\end{array}$ \\
\hline 0.0 & $28.0 \pm 3.79 a$ & $33.0 \pm 1.00 \mathrm{a}$ & $25.3 \pm 2.03 \mathrm{a}$ & $25.7 \pm 4.70 \mathrm{a}$ \\
\hline 0.2 & $15.3 \pm 1.45 b$ & $13.0 \pm 0.58 b$ & $15.0 \pm 1.73 b$ & $12.7 \pm 1.76 b$ \\
\hline 0.4 & $15.0 \pm 1.73 b$ & $11.0 \pm 0.58 b$ & $15.3 \pm 1.33 b$ & $7.0 \pm 1.15 b c$ \\
\hline 0.6 & $12.7 \pm 2.60 b$ & $12.0 \pm 1.73 b$ & $12.7 \pm 2.60 b$ & $4.7 \pm 0.67 \mathrm{bcd}$ \\
\hline 0.8 & $7.3 \pm 0.88 \mathrm{c}$ & $5.0 \pm 1.15 \mathrm{c}$ & $7.3 \pm 0.88 c$ & $2.0 \pm 0.58 \mathrm{~cd}$ \\
\hline 1.0 & $2.3 \pm 0.67 \mathrm{c}$ & $1.0 \pm 1.00 \mathrm{c}$ & $2.0 \pm 1.00 \mathrm{c}$ & $1.0 \pm 0.03 \mathrm{~d}$ \\
\hline
\end{tabular}

It was observed that the percentage weight loss of cowpea seeds treated with powders and ashes of ripe and unripe C. papaya seed followed a similar trend as with the adult emergence (Table 5). The mean weight loss of cowpea seeds treated with different rates of powder and ash of ripe and unripe $C$. papaya seed were significantly different $(\mathrm{p}<0.05)$ from that of the control. There was no significant difference between data obtained at cowpea seeds treated with ripe $C$. papaya seed powder at application rates of $0.2 \mathrm{~g}$ and $0.4 \mathrm{~g}$. Also, there was no significant difference $(\mathrm{p}>0.05)$ between cowpea seeds treated with ripe $C$. papaya seed powder at application rates of $0.8 \mathrm{~g}$ and $1.0 \mathrm{~g}$. Seeds treated with ripe $C$. papaya seed ash at application rates of $0.2 \mathrm{~g}, 0.4 \mathrm{~g}$ and $0.6 \mathrm{~g}$ were not significantly different from one another. Cowpea seeds treated with $0.8 \mathrm{~g}$ and $1.0 \mathrm{~g}$ application rates of ripe $C$. papaya seed ash were not significantly different, but were significantly lower than the untreated control. It was generally observed that seed weight loss decreased significantly with increase in application rates of the applied materials. Cowpea seeds treated with $1.0 \mathrm{~g}$ of powder and ash of ripe $C$. papaya seed significantly reduced seed weight loss compared to the control and a similar trend was observed for cowpea seeds treated with powders and ashes of unripe C. papaya seed. 
Table 5. Mean Percentage Seed Weight loss after F1 adult emergence in cowpea treated with different application rates of powder and ash of $C$. papaya seed.

\begin{tabular}{|c|c|c|c|c|}
\hline $\begin{array}{l}\text { Concentration } \\
\text { of Powder/Ash } \\
\text { (g) }\end{array}$ & $\begin{array}{c}\text { Ripe C. papaya } \\
\text { Powder }\end{array}$ & $\begin{array}{c}\text { Unripe C. } \\
\text { papaya } \\
\text { Powder }\end{array}$ & $\begin{array}{c}\text { Ripe C. papaya } \\
\text { Ash }\end{array}$ & $\begin{array}{c}\text { Unripe C. } \\
\text { papaya } \\
\text { Ash }\end{array}$ \\
\hline 0.0 & $1.2 \pm 0.08 \mathrm{a}$ & $1.2 \pm 0.08 \mathrm{a}$ & $1.2 \pm 0.08 a$ & $1.2 \pm 0.08 a$ \\
\hline 0.2 & $1.1 \pm 0.03 \mathrm{ab}$ & $0.9 \pm 1.10 b$ & $1.0 \pm 0.05 b$ & $0.9 \pm 0.06 b$ \\
\hline 0.4 & $1.0 \pm 0.02 b c$ & $0.7 \pm 0.03 b$ & $0.8 \pm 0.03 b$ & $0.6 \pm 0.03 c$ \\
\hline 0.6 & $0.9 \pm 0.03 c$ & $0.6 \pm 0.03 c$ & $0.7 \pm 0.03 b$ & $0.5 \pm 0.02 \mathrm{~cd}$ \\
\hline 0.8 & $0.7 \pm 0.02 d$ & $0.4 \pm 0.04 d$ & $0.5 \pm 0.03 c$ & $0.3 \pm 0.04 d$ \\
\hline 1.0 & $0.6 \pm 0.02 d$ & $0.3 \pm 0.06 \mathrm{e}$ & $0.5 \pm 0.03 c$ & $0.1 \pm 0.02 e$ \\
\hline
\end{tabular}

Each value is the mean \pm standard error of the three replicates. Values in the same column with the same letter(s) do not differ significantly at $\mathrm{p} \leq 0.05$ using Tukey's honest significance test

Table 6 shows the mean weevil perforation index in cowpea seeds treated with different application rates of powder and ash of ripe and unripe $C$. papaya seeds. The results obtained from the table showed that there was a significant impact of the powder and ash of ripe and unripe $C$. papaya seeds on the cowpea seeds than the untreated seeds. $1.0 \mathrm{~g}$ application rate recorded the lowest mean weevil perforation index $(\operatorname{Ripe} C$. papaya Powder $=16.4$, Unripe $C$. papaya Powder $=13.5$, Ripe $C$. papaya Ash = 14.9 and Unripe $C$. papaya ash = 10.8). Among the treated seeds, irrespective of the treatment $0.2 \mathrm{~g}$ dosage rate had the highest weevil perforation index compared to other application rates. In all, $1.0 \mathrm{~g}$ application rate of unripe $C$. papaya ash recorded the least mean weevil perforation index. Both the dosage rates of 0.8 and $1 \mathrm{~g}$ were found to be more effective in reducing the grains damage when compared with the untreated seeds. 
Table 6. Mean Weevil Perforation Index in cowpea treated with different application rates of powder and ash of $C$. papaya seed.

\begin{tabular}{|c|c|c|c|c|}
\hline $\begin{array}{l}\text { Concentration } \\
\text { of Powder/Ash } \\
\text { (g) }\end{array}$ & $\begin{array}{c}\text { Ripe C. papaya } \\
\text { Powder }\end{array}$ & $\begin{array}{c}\text { Unripe C. } \\
\text { papaya } \\
\text { Powder }\end{array}$ & $\begin{array}{c}\text { Ripe C. papaya } \\
\text { Ash }\end{array}$ & $\begin{array}{c}\text { Unripe C. } \\
\text { papaya } \\
\text { Ash }\end{array}$ \\
\hline 0.0 & $51.7 \pm 1.34 a$ & $45.2 \pm 1.21 \mathrm{a}$ & $51.7 \pm 6.16 a$ & $44.4 \pm 2.50 \mathrm{a}$ \\
\hline 0.2 & $42.7 \pm 3.21 \mathrm{ab}$ & $28.9 \pm 2.76 a b$ & $37.6 \pm 1.21 \mathrm{ab}$ & $27.1 \pm 1.39 a$ \\
\hline 0.4 & $37.5 \pm 2.05 b$ & $25.8 \pm 3.15 b c$ & $34.1 \pm 0.91 b c$ & $25.7 \pm 0.75 a$ \\
\hline 0.6 & $30.6 \pm 1.43 \mathrm{bc}$ & $20.6 \pm 1.14 b c d$ & $25.8 \pm 1.94 \mathrm{bcd}$ & $19.3 \pm 0.95 a b$ \\
\hline 0.8 & $22.1 \pm 1.26 c$ & $16.9 \pm 2.08 \mathrm{~cd}$ & $20.9 \pm 2.57 \mathrm{~cd}$ & $14.9 \pm 2.21 b c$ \\
\hline 1.0 & $16.4 \pm 1.14 c$ & $13.5 \pm 2.93 d$ & $14.9 \pm 3.07 d$ & $10.8 \pm 5.06 c$ \\
\hline
\end{tabular}

Each value is the mean \pm standard error of the three replicates. Values in the same column with the same letter(s) do not differ significantly at $\mathrm{p} \leq 0.05$ using Tukey's honest significance test

Table 7 shows the mean percentage germination of cowpea seeds treated with different application rates of powder and ash of $C$. papaya seed. There exist no significant difference between seeds treated with ripe $C$. papaya powder at application rates of $0.2 \mathrm{~g}, 0.4 \mathrm{~g}, 0.6 \mathrm{~g}$, $0.8 \mathrm{~g}$ and $1.0 \mathrm{~g}$ respectively. Also, seeds treated with ripe $C$. papaya ash at application rates of $0.6 \mathrm{~g}, 0.8 \mathrm{~g}$ and $1 \mathrm{~g}$ were not significantly different from one another. $1.0 \mathrm{~g}$ application rate had the highest mean percentage germination of cowpea seeds irrespective of the treatment. $100 \%$ mean percentage germination of cowpea seeds was also recorded at $0.8 \mathrm{~g}$ application rate of unripe $C$. papaya seed powder and unripe $C$. papaya seed ash and they were significantly different from the untreated control. 
Table 7. Mean Percentage Germination of cowpea treated with different application rates of powder and ash of $C$. papaya seed.

\begin{tabular}{|c|c|c|c|c|}
\hline $\begin{array}{l}\text { Concentration } \\
\text { of Powder/Ash } \\
\text { (g) }\end{array}$ & $\begin{array}{c}\text { Ripe C. papaya } \\
\text { Powder }\end{array}$ & $\begin{array}{c}\text { Unripe C. } \\
\text { papaya } \\
\text { Powder }\end{array}$ & $\begin{array}{c}\text { Ripe C. Papaya } \\
\text { Ash }\end{array}$ & $\begin{array}{c}\text { Unripe C. } \\
\text { papaya } \\
\text { Ash }\end{array}$ \\
\hline 0.0 & $60.0 \pm 5.77 a$ & $60.0 \pm 5.77 a$ & $70.0 \pm 5.77 a$ & $70.0 \pm 5.77 a$ \\
\hline 0.2 & $86.7 \pm 3.33 \mathrm{ab}$ & $86.7 \pm 3.33 \mathrm{ab}$ & $86.7 \pm 3.33 \mathrm{ab}$ & $86.7 \pm 3.33 a$ \\
\hline 0.4 & $86.7 \pm 3.33 \mathrm{ab}$ & $93.3 \pm 3.33 b$ & $90.0 \pm 0.00 a b$ & $86.7 \pm 0.00 \mathrm{ab}$ \\
\hline 0.6 & $90.0 \pm 5.77 b$ & $93.3 \pm 3.33 b$ & $93.3 \pm 3.33 b c$ & $96.7 \pm 3.33 b c$ \\
\hline 0.8 & $93.3 \pm 3.33 b$ & $100.0 \pm 0.00 b$ & $96.7 \pm 3.33 c$ & $100.0 \pm 0.00 c$ \\
\hline 1.0 & $100.0 \pm 0.00 b$ & $100.0 \pm 0.00 b$ & $100.0 \pm 0.00 c$ & $100.0 \pm 0.00 c$ \\
\hline
\end{tabular}

Each value is the mean \pm standard error of the three replicates. Values in the same column with the same letter(s) do not differ significantly at $\mathrm{p} \leq 0.05$ using Tukey's honest significance test.

\section{Discussion}

This study has shown that plant powder and ash of $C$. papaya seed used in the research had significant $(\mathrm{P} \leq 0.05)$ effect on the mortality of adult $C$. maculatus on cowpea seeds. The seed powder and ash used were observed to have varying insecticidal potency against $C$. maculatus at varying amounts applied. However, powder and ash from unripe $C$. papaya seed showed better protection of cowpea seed against infestation by $C$. maculatus. Powder and ash of unripe $C$. papaya seed at 0.8 and $1.0 \mathrm{~g} / 20 \mathrm{~g}$ of cowpea seed caused $100 \%$ mortality of adult bruchids at 72 hours post treatment. Powder and ash of ripe $C$. papaya seed were also observed to be effective against $C$. maculatus after 72 hours causing more than $83.3 \%$ mortality at $1.0 \mathrm{~g} / 20 \mathrm{~g}$ of cowpea seeds. This agrees with findings reported by Franco-Archundia et al. (2006) where it was reported that $90 \%$ mortality was observed after 72 hours in the presence of 33,600 ppm with four varieties (Hawaiian, Mamey, Maradol, and Yellow) of C. papaya against Spodoptera frugiperda.

The results of this study showed that treatment of cowpea seeds with ripe powder, unripe 
powder, ripe ash and unripe ash of $C$. papaya seed decreases the oviposition of $C$. maculatus with increase in concentration treatment. The reduction in oviposition by $C$. maculatus could be due to the oviposition deterrence characteristics possessed by $C$. papaya seed products and high mortality of $C$. maculatus recorded, which could be linked to its toxic effect. This agrees with the findings of Ojo et al., (2013) who reported that the deterrence of oviposition of $C$. maculatus by the moringa leaf powder were concentration-dependent. The number of F1 progeny by $C$. maculatus on cowpea seed was lowest with unripe $C$. papaya seed product. This shows the superiority of seed products from unripe $C$. papaya seed in suppressing adult emergence from the eggs laid by parents that were not killed by the treatment toxicity. The reduction in adult emergence could either be due to egg mortality, or larval mortality or even reduction in the hatching of the eggs. It has been reported that the larvae which hatch from the eggs of Callosobruchus must penetrate the seeds to survive (FAO, 1999). The larvae would be unable to do so unless the eggs are firmly attached to the seed surface. It could also be as a result of feeding deterrence resulting in the death of the insects leading to reduced progeny production and has been the case with other plant materials investigated (Tapondjou et al., 2002; Abdelgaleil and Nakatani, 2003) as it was also observed in this study.

The reduction in seed weight loss and damage observed on the treated seeds could be a result of the reductive effect of the feeding of the larva on the grains. This could be due to the biochemical constituents of the unripe $C$. papaya seed product as it recorded the lowest seed damage. This is consistent with the results of Idoko (2015) who reported the effectiveness of powders and extract from ripe and unripe banana peel and the results showed that the powder and extract from unripe banana peel were more effective than the ripe banana peel.

Damage caused by $C$. maculatus infestation was significantly reduced after cowpea seeds were treated with seed products of $C$. papaya compared to the untreated control. This was evident with low seed weight loss and low weevil perforation index observed among the treated seeds. Despite the low seed weight loss recorded for cowpea seed treated with seed products of $C$. papaya, weevil perforation index was generally high (>15) across the rates used. The exceptions to the high WPI were application rates of $1 \mathrm{~g}$ of unripe and ripe $C$. papaya seed ash and unripe seed powder that resulted in weevil perforation indexes of 10.8 , 14.9 and 13.5 respectively, while $0.8 \mathrm{~g}$ of unripe seed ash resulted in a WPI of 14.9.

The results also showed that germination (\%) was significantly enhanced with increase in the application rates of seed products from ripe and unripe $C$. papaya seed on cowpea such that $100 \%$ germination was recorded with virtually all the treatments at $1 \mathrm{~g}$. The high insecticidal activity by the products of $C$. papaya seed can be attributed to their constituents that could be rich in bioactive chemicals. The study of Konno et al., (2003), Farias et al. (2007) and Tatun et al. (2014) revealed that the seeds of $C$. papaya consist of cysteine proteases, papain and $\alpha$-amylase inhibitors which showed higher insect mortality. The study of Tatun et al.(2014) showed that $\alpha$-amylase inhibitors extracted from papaya seeds increased larval mortality by up to $50 \%$ and decreased insect fecundity. Also, Pérez-Gutiérrez et al. (2014) in their study reported that $C$. papaya contained seven components, among which the main constituents were oleic, palmitic, linoleic, and stearic acids, with relative percentage values of $76.75 \%$, $12.89 \%, 4.11 \%$, and $3.96 \%$, respectively which have insecticidal effects. 


\section{Macrothink}

Journal of Agricultural Studies

ISSN 2166-0379 2018, Vol. 6, No. 3

A plausible explanation for the insecticidal effect of products from unripe $C$. papaya seed showing greater insecticidal effect than ripe seeds in this study may be due to the fact that chemical reaction during the process of ripening have converted the insecticidal chemicals to less harmful ones. This was in accordance with the findings of Emaga et al. (2007) who reported that maturation and ripening in banana fruit is certainly accomplished by degradation of endogenous enzymes. The toxicity potential of the products of ripe and unripe C. papaya seed could be traced to some of the active substances (e.g. carpine and papain) present in the seed (Eno et al., 2000). This study also showed that the products from seed of unripe $C$. papaya are effective to protect cowpea seeds in the store and the farmers can easily prepare it and apply it to protect their grain in the store.

The study has clearly demonstrated the potentials of the powder and ash of ripe and unripe $C$. papaya seed as plant derived insecticides against Callosobruchus maculatus in stored cowpea. In developing countries, especially in Nigeria, the use of insecticidal plant materials can greatly contribute to fight food insecurity by reducing post harvest losses as the plants are locally available.

However, there is need to carry out laboratory analysis of the powder and ash from seeds of Carica papaya so as to identify the active ingredient/s responsible for the insecticidal activity on C. maculatus. 


\section{References}

Abdegaleil, S. A. M., \& Nakatani, M. (2003). Antifeeding activity of limonoids from Khaya senegalensis (Meliaceae). Journal of Applied Entomology, 127, 236-239.

Azevedo, L. A., \& Campagnol, P. C. B. (2014). Papaya seed flour (Carica papaya) affects the technological and sensory quality of hamburgers. International Food Research Journal, 21(6), 2141-2145.

Bekele, A. J., \& Hassanali, A. (2001). Blend effects in the toxicity of the essential oil constituents of Ocimum kilm and scharicum and Ocimum kenyense (Labiateae) on two Post-harvest insect pests. Phytochemistry, 57, 385-391.

Berger, M. (1994). Using natural pesticides. Current and future perspectives: Swedish University of Agricultural Sciences, Uppsala, 6-9.

Chitamba, J., Manjeru, P., Chinheya, C. C., \& Handiseni, M. (2013). Evaluation of legume intercrops on population dynamics and damage level of $R$. similis in banana (Musa spp.). Archives of Phytopathology and Plant Protection.

Edward, A. E., \& Fredy, H. B. (2015). An Overview of Global Papaya Production, Trade, and Consumption, Food and Resource Economics Department (https://edis.ifas.ufl.edu/pdffiles/FE/FE91300.pdf) October 6, 2017.

Emaga. T. H., Andrianaivo. R. H., Wathelet. B., Tchango. J. T., \& Paquot, M. (2007). Effects of the stage of maturation and varieties on the chemical composition of banana and plantain peels. Food Chemistry, 103, 590-600.

Eno, A. E., Owo, O. I., Itam, E. H., \& Konya, R. S. (2000). Blood pressure depression by the fruit juice of Carica papaya (L.) in renal and DOCA-induced hypertension in the rat, Phytotherapy Research, 14(4), 235-239.

FAO (1999).http://www.fao.org/inpho/maize (Internet information Accessed on 23 March, 2017).

Farias, J. R. B., Nepomuceno, A. L.,\& Neumaier, N. (2007). Ecofi siologia da soja. Londrina: Embrapa Soja, 9 (Embrapa Soja. Circular técnica, 48).

Franco-Archundia, S. L., Jiménez-Pérez, A., Luna-León, C., \& Figueroa-Brito, R. (2006). Efecto tóxico de semillas de cuatro variedades de Carica papaya(Caricaceae) en Spodoptera frugiperda (Lepidoptera: Noctuidae). Folia Entomol. Mex., 45, 171-177.

Idoko, J. E. (2015). Entomotoxic effects of banana peel extract and powder against Callosobruchus maculatus (F.) infesting cowpea in storage In: Amos, T.T. Adekunle, V.A.J. and Badejo, A.A. (Editors): Food security and climate change: The way forward, Proceedings of the 8th Annual Agricultural Conference, The Federal University of Technology Akure, Nigeria. pp. 103-106.

Konno K, Hirayama C, Nakamura M, Tasheishi K, Tamura Y and Hattori M. (2003). Papain protects papaya trees from herbivorous insects: role of cysteine proteases in latex. The Plant 
Journal, 37(3), 370-378.

Ofuya, T. I., Olotuah O. F., \& Akinyoade D. O. (2010). The Effect of Storage on the Efficacy of Eugenia aromatica (Baill.) in the control of Callosobruchus maculatus (Fabricius) (Coleoptera: Bruchidae) Pest. J. Appl. Sci. Environ. Manage, 14(1), 97-100.

Ojo, J., Olunloyo, A., \& Akanni, E. (2013). Efficacy of Moringa oleifera leaf powder against Callosobruchus maculatus (F.) (Coleoptera: Chrysomelidae) on stored cowpea (Vigna unguiculata L. Walp). Researcher, 5(12), 240-244.

Pérez-Gutiérrez, S., Zavala-Sánchez, M., González-Chávez, M., Cárdenas-Ortega, N., \& Ramos-López, M. (2014). Bioactivity of Carica papaya (Caricaceae) against Spodoptera frugiperda(Lepidoptera: Noctuidae). Molecules, 16, 7502-7509.

Porte, A., Silva, E. F., Almeida, V. D. S., Silva, T. X., \& Porte, L. H. M. (2011). Propriedades funcionais tecnológicas das farinhas de sementes de mamão (Carica papaya) e de abóbora (Cucurbita sp). Revista Brasileira de Produtos Agroindustriais, 13(1), 91-96.

Tapondjou, L. A., Adler, C., Bouda, H., \& Fontem, D. A. (2002). Efficacy of powder and essential oil from Chenopodium ambrosioides leaves as post harvest grain protectants against six-stored product beetles. J. Stored Prod. Res., 38(4), 395-402.

Tarver, R., Shade, M. E., Tarver, R. D., Liang, R., Krishnamurthi, G., Pittendrigh, B., \& Murdock, L. (2006). Use of micro-CAT scans to understand cowpea seed resistance to Callosobruchus maculatus. Entomologia Experimentalis Et Applicata, 118, 33-39.

Tatun, N., Vajarasathira B., Tungjitwitayakul, J., \& Sakurai, S. (2014). Inhibitory effects of plant extracts on growth, development and $\alpha$-amylase activity in the red flour beetle Tribolium castaneum (coleoptera: tenebrionidae). Eur. J. Entomol., 111(2), 181-188.

\section{Copyright Disclaimer}

Copyright for this article is retained by the author(s), with first publication rights granted to the journal.

This is an open-access article distributed under the terms and conditions of the Creative Commons Attribution license (http://creativecommons.org/licenses/by/4.0/). 